\title{
Rumen microbial degradation of modified lignin plants observed by electron microscopy
}

\author{
C Migné, E Grenet, MA Bernard, JM Besle, A Cornu
}

INRA, SRNH, Unité de la Digestion Microbienne, Theix, 63122 St-Genès-Champanelle, France

The microbial degradation of modified lignin tobacco (Samson variety) plants (homozygous line 40 ), produced by genetic engineering was studied by microscopy. Fourteen-week-old tobaccos plants, grown in a greenhouse, were used for the study. The modification inhibited the expression of the cinnamyl alcohol dehydrogenase (CAD) gene. This enzyme (CAD) catalyses the reduction of the cinnamyl aldehydes to the corresponding cinnamyl alcohols which are the direct monomeric precursors of the lignin. Only the stems were studied. They were cut into three equal parts : the top, middle and bottom internodes.

The digestibility in situ of dry matter after $48 \mathrm{~h}$ in the rumen was measured by the nylon bag method. The results were as follow : 68.8 $\pm 0.8 \%$ (top), $65.8 \pm 1.4 \%$ (middle) and 60.6 $\pm 1.8 \%$ (bottom) in the control plants and 66.6 $\pm 1.8 \%, 65.7 \pm 0.9 \%$ and $62.1 \pm 2.0 \%$ respectively in engineered plants. The results show only a non significant improvement of the digestibility in the bottom internode of modified plants compared to control plants.

The bottom internodes were chosen for the microscopical investigations. Two specific stainings of lignins with light microscope were used : acid phloroglucinol which characterize the lignin rich in cinnamaldehydes and the Mäule reactant which characterize the lignin rich in syringyl units. Acid phoroglucinol stained the xylem of control plants pink and that of engineered plants orange-red, whereas the Mäule reactant stained the xylem of both samples red. The natural colour of the engineered tobacco plants was orange, and this may have affected the staining. The xylem ring was thinner in engineered plants than in control plants.

The anatomy and the ultrastructure of the plants were observed by scanning electron microscopy (SEM) and transmission electron microscopy (TEM). Observations before incubation in the rumen showed no differences between control and engineered plants. Samples were put in nylon bags and were introduced in the rumen for $4 \mathrm{~h}, 8 \mathrm{~h}, 24 \mathrm{~h}, 48 \mathrm{~h}$ and $72 \mathrm{~h}$. As from the first hours of degradation $(8 \mathrm{~h})$ the non-lignified tissues : the pith, the cambium, the phloem and the parenchyma of the stem were degraded in both types of sample and the xylem (lignified tissue) cell walls were heavily colonised by bacteria. After $24 \mathrm{~h}$, the cell walls of the xylem fibres were thinner in the engineered plant than in control as show by SEM ; the secondary cell walls of the xylem fibres of the engineered plant were degraded by numerous bacteria, giving them a scalloped appearance, as show by TEM. After $72 \mathrm{~h}$, the extent of degradation was the same in both sample types. The vessel cell walls were at no time degraded.

In conclusion, the cell walls of the xylem fibres were degraded sooner in the engineered plant than in control, which evidence that the ultrastructure of cell wall fibres was modified. However, this modification was not sufficient, under our experimental conditions, to significantly improve stem digestibility. 